\title{
Antibacterial Activities of Staphylococcus sciuri APD7 Isolate Sponge-Associated Aplysina sp. Against Escherichia coli, Pseudomonas aeruginosa and Staphylococcus aureus
}

\author{
Delfiani Anggias Putri ${ }^{1}$ Risky Hadi Wibowo ${ }^{2, *}$ Sipriyadi $^{2}$ Welly Darwis ${ }^{2}$ Choirul \\ Muslim² Salprima Yudha $^{3}$ Hizkia Puspa Pertiwi ${ }^{4}$ \\ ${ }^{1,4}$ Undergraduate Student, Department of Biology, Faculty of Mathematics and Natural Sciences, Universitas \\ Bengkulu, Kandang Limun, Bengkulu 38112, Indonesia \\ ${ }^{2}$ Department of Biology, Faculty of Mathematics and Natural Sciences, Universitas Bengkulu, Kandang Limun, \\ Bengkulu 38112, Indonesia \\ ${ }^{3}$ Department of Chemistry, Faculty of Mathematics and Natural Sciences, Universitas Bengkulu, Kandang \\ Limun, Bengkulu 38112, Indonesia. \\ *Corresponding author. Email: riskyhadiwibowo80@gmail.com
}

\begin{abstract}
Sponges including multicellular animals, do not have actual tissues and organs, and are the simplest animals structurally. Sponges are also a group of marine life that is symbiotic with the microbial community. Microbes that have formed a symbiotic relationship with a sponge will produce secondary metabolites which also protect their host from pathogens. The sponge used in this study is the Aplysina sp. sponge collected from Enggano island, Bengkulu Province. Aplysina sp sponge is known to contain metabolites with antimicrobial, repellent properties, fighting predators, cytotoxic activity of breast cancer cells, has an antibiotic and anti-inflammatory effect on gram-positive bacteria. This study aims to identify of potential isolates associated with Aplysina sp. sponge collected from Enggano island. Isolation of bacteria from Aplysina sp. sponge using Sea Water Complete (SWC) media. The isolates were screened by antagonistic test, morphological characters, Gram-staining, biochemical test and molecular identification. Based on the antagonistic test, APD7 isolate could inhibit Escherichia coli, Pseudomonas aeruginosa and Staphylococcus aureus in vitro. APD7 isolate was identified molecularly using of $16 \mathrm{~S}$ rRNA genes analysis and it genetically close with Staphylococcus sciuri.
\end{abstract}

Keywords: Aplysina sp, Enggano island, Antibacterial activity, Identification of 16S rRNA gene

\section{INTRODUCTION}

Pathogenic microbes are one of the pathogenic biological agents that cause infectious diseases and become a problem in the world of health. Infectious pathogens can be bacteria, viruses, parasites, or fungi. This disease is dynamic, can spread directly or indirectly from one person to another.

Based on research conducted by [1], sponges are known to be the most secondary metabolite producing organism, where these bioactive compounds are produced through symbiotic relationships with other microbes. Secondary metabolites produced by sponges are not only used for the self-defense system, but have many functions, especially for medicine.

Sponges are filter feeder organisms that can filter thousands of liters of seawater per day. On the surface of the sponge body there is a small hole (ostium) that serves as a place for water and organic particles to enter. Sponges can be a host of various types of microbes which can amount to $50-60 \%$ of the body [2]. Thus, the secondary metabolites produced by microbes support the survival of the sponge against competitors or predators [3]. 
Sponges from Aplysinidae family contain brominated alkaloids with cytotoxic activity and predatory in mosquitoes [4,5]. Aplysina sp. sponges are also known to contain high concentrations of brominated metabolites with antimicrobial activity, repellent properties, fighting predators, cytotoxic activity of breast cancer cells, has an antibiotic and anti-inflammatory effect on gram-positive bacteria [6]. Based on the description above, it is necessary to conduct research on the identification of spongeassociated bacteria and their potency to produce of antibacterial compounds.

\section{MATERIALS AND METHODS}

\subsection{Research Material}

The tools and materials used in this study were mortar and pestle, Erlenmeyer, measuring cups, Petri dishes, test tubes, test tube racks, beakers glass, bunsen burner, loop needles, drop pipette, analytical scales, centrifuge, autoclave, UV-Laminar flow-hood, incubators, refrigerators, hot plate, magnetic stirrer, spreader rod, glass objects, cover glass, micropipette, serology pipete $10 \mathrm{ml}$ and $1 \mathrm{ml}$, digital calipers, microscope, Polimerase Chain Reaction (PCR), electrophoresis, Gel Documentation, label papper, cotton, tissue, marker, ruler, Aplysina sp sponge, TSA (Tryptic Soy Agar), Sea Water Complete (SWC), disc paper (Whatman $6 \mathrm{~mm}$ ), confectionery medium, test microb isolates consisting of Escherichiacoli, Pseudomonas aeruginosa and Staphylococcus aureus, alcohol 70\%, alcohol 96\%, distilled water, spritus, crystal violet, lugol, immersion oil, safranin, hydrogen peroxide $\left(\mathrm{H}_{2} \mathrm{O}_{2}\right)$, wrapping paper, and aluminum foil, 63F/1387R primers of 16S rRNA, Presto ${ }^{T M}$ Mini gDNA Bacteria (Geneaid) kit protocol, GoTag Green Mastermix kit $\mathrm{PCR}$, nuclease free water (NFW), agarose $1 \%$, ethidium bromide (EtBr) dye.

\subsection{Aplysina sp. Sponges Collection}

Aplysina sp. sponge samples were collected from the waters of Dua Island, Enggano Island located in North Bengkulu Regency. The samples obtained were immediately carried out in the preparation. Furthermore, the analysis of sample isolates were tested in the Microbiology Laboratory, Biotechnology and Genetics Laboratory, University of Bengkulu.

\subsection{Isolation of Bacteria Associated with the Aplysina sp. Sponge}

One gr of sponge body crushed with a sterile mortar and pestle, then diluted with $\mathrm{NaCl} 0.85 \%$ as much as $9 \mathrm{~mL}$ and serial dilutions were carried out from $10^{-1}$ to $10^{-3}$. Each dilution,- pipette $0.1 \mathrm{~mL}$ aseptically spread into a Petri dish containing sterile Sea Water Complete (SWC) media, then, incubated at $30{ }^{\circ} \mathrm{C}$ for 48 hours [7].

\subsection{Purification of Bacteria Associated with the Aplysina sp. Sponge}

Purification of bacteria associated with the sponge was carried out by using the streak method on a Petri dish containing sterile SWC media. Isolates of bacteria were incubated in the incubator at $30{ }^{\circ} \mathrm{C}$ for 48 hours. The morphology of the bacterial colonies that grew on the media was observed based on their margin, texture, form, elevation, and color of the colony.

\subsection{Antagonistict Test of Bacterial Isolates Producing Bioactive Compounds Using Culture, Pellets and Supernatant Methods}

Antagonist test of bacteria were carried out using the test of pathogenic microbes, such as Escherichia coli, Pseudomonas aeruginosa and Staphylococcus aureus. Previously, pathogenic microbes were regenerated first, preparation of pathogenic microbes for antagonistic tests was carried out by culturing the pathogenic microbes for 24 hours. Then, $1 \mathrm{~mL}$ of pathogenic microbial culture was put into $40 \mathrm{~mL}$ of TSA medium was still liquid, and poured into a sterile Petri dish. After the medium was solid, the pure bacterial isolates were streaked on the surface of the media containing the tested bacterial culture, then incubated at $37{ }^{\circ} \mathrm{C}$ for 24 hours. Positive result indicated by a clear zone around the colony. The area of the clear zone is measured using a digital caliper.

The isolates which have the largest zone of inhibition and inhibit the test pathogens will be selected for the furture test. Selected isolates from the antagonistic test used culture and recultured on liquid SWC media for 24 hours. Then, $1.5 \mathrm{~mL}$ of bacterial culture was centrifuged at rpm for 5 minutes. The pellets were dissolved in $150 \mu \mathrm{L}$ of supernatant, the as much as $20 \mu \mathrm{L}$ of the pellets were dropped on as disc paper and left to stand for 10 minutes until the disc paper was dry. After that, the disc paper was placed on the SWC media containing the test microbes, then incubated at $37^{\circ} \mathrm{C}$ for 24 hours.

The supernatant resulted from the centrifugation process was separated for use in the antagonistic test against the test microbes. The antagonist test was carried out using a sterile disc paper that had been 
dropped with supernatant as much as $20 \mu \mathrm{L}$ and left for 10 minutes, then placed on the media containing the test microbes. Positive results by used of the pellet and supernatant methods were indicated by the formation of a clear zone around the paper disc. The clear zones formed by these methods were compared with 4 categories of inhibition of antimicrobial compounds according to [8].

\subsection{Identification of APD7 Isolate (Morphological characters, Gram Staining and Biochemical Test)}

Gram staining was done by placing 1 loop of bacterial isolate from the previous test into the object glass aseptically. Then given a solution of crytal violet, lugol, alcohol $96 \%$ and safranin one drop each, then rinsing under running water in each stage [9]. Identification of bacterial colonies using biochemical tests, such as catalase test, motility test, urea test, carbohydrate fermentation test, and citrate test were done.

\subsection{Genomic extraction of APD7 isolate}

APD7 isolate were purified in solid SWC media and incubated at at $30^{\circ} \mathrm{C}$ for 48 hours. 3-4 ose of this isolate were put into a micro sterile tube/ Eppendorf tube containing $0.5 \mathrm{~mL}$ nuclease free water (NFW) and centrifuged at a speed of $12000 \mathrm{rpm}$ for 5 minutes and DNA genom was isolated using Presto $^{T M}$ Mini gDNA Bacteria (Geneaid) kit protocol. Isolation of bacterial genomic DNA based on the results of gram staining on these bacteria. Genomic DNA isolation stages include isolate sample preparation, cell lysis, DNA binding, DNA washing, DNA elution. Procedures are carried out according to the manufacturer's instructions.

\subsection{Molecular Identification of the APD7 isolate Based on 16S rRNA Genes}

16S rRNA genes were amplified using the forward primer 63F (5'-CAG GCC TAA CAC ATG CAA GTC-3') and reverse primer 1387R (5'-GGG CGG WGT GTA CAA GGC-3') [10] with target fragment of $1300 \mathrm{pb}$. The total volume of the reaction used was $40 \mu \mathrm{L}$ consisting of $20 \mu \mathrm{L}$ GoTaq Green Mastermix $2 x$, each of $2 \mu \mathrm{L}$ primers, DNA template 4 $\mu \mathrm{L}(\sim 100 \mathrm{ng})$ and nuclease free water (NFW) $12 \mu \mathrm{L}$. Amplification was performed under PCR conditions at pre-denaturation $\left(94^{\circ} \mathrm{C}, 5\right.$ minutes $)$, denaturation ( $94^{\circ} \mathrm{C}, 45$ second), annealing $\left(55^{\circ} \mathrm{C}, 1\right.$ minutes), elongation (72 ${ }^{\circ} \mathrm{C}, 1$ minutes 10 second). Denaturation, anneling ang elongation were repeated for 30 cycles. At the next stage, post elongation (72 ${ }^{\circ} \mathrm{C}, 7$ minutes $)$, and cooling $\left(15^{\circ} \mathrm{C}, 15\right.$ minutes $)$.

\section{RESULTS AND DISCUSSION}

\subsection{Bacterial Isolates from Sponge Aplysina sp}

The results of bacterial isolation associated with the Aplysina sp. sponge obtained various bacterial colonies that grew on agar media. The colonies that grew from each dilution were screened based on morphological characters, such as margin, texture, form, elevation, and color of the colony. Each colony that has different morphological characters is purified for observation and screening.

\subsection{Activity of Bacteria Producing Bioactive Compounds}

Based on the screening results, there are 16 bacterial isolates that have different morphological characters and showed antibacterial activities against Escherichiacoli, Pseudomonas aeruginosa and Staphylococcus aureus. One of the selected isolate that has antagonistic activities namely APD7 isolate.

Growth inhibitory activity against pathogenic bacteria is characterized by the presence of a clear zone around the colony/disc paper. Bacterial isolates in symbiosis with the Aplysina sp. sponge have different abilities in inhibiting the growth of pathogens. The results of the activity test of bacteria producing bioactive compounds using culture methods, pellets, and supernatants showed that the ability of each isolate to produce clear zone areas was different for each isolate. There are four categories of inhibitory activity of antimicrobial compounds based on the clear zone according to [8] namely diameter $(\mathrm{mm})>20$ activity of the inhibition zone is very strong, 10-20 activity of the inhibition zone is strong, 5-10 activity of the inhibition zone is moderate, and $<5$ activity of the inhibition zone is weak. The different in these activities can be seen in Figure 1 and Table 1. 


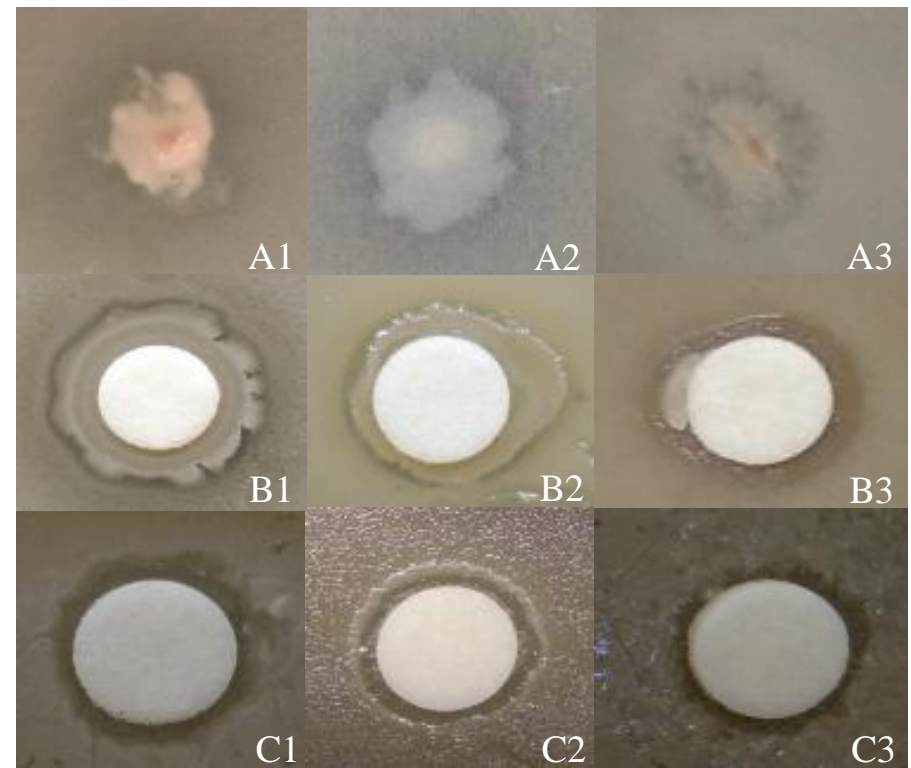

Figure 1. The clear zone produced by APD7 isolate against Escherichia coli (1), Pseudomonas aeruginosa (2) and Staphylococcus aureus (3); A = Clear zone form by culture, B = Clear zone formed by pellets, and $\mathrm{C}=$ Clear zone formed by supernatant

Table 1. Antibacterial activities of APD 7 isolate sponge-associated Aplysina sp.

\begin{tabular}{|c|c|c|c|c|c|c|}
\hline Sampel code & $\begin{array}{l}\text { Antagonism } \\
\text { Assay of }\end{array}$ & Microb test & $\begin{array}{l}\text { Disc/culture } \\
\text { Diameter } \\
(\mathrm{mm}) \pm \mathrm{SD}\end{array}$ & $\begin{array}{c}\text { Isolate } \\
\text { diameter }+ \\
\text { zone of } \\
\text { inhibiton } \\
(\mathrm{mm}) \pm \mathrm{SD} \\
\end{array}$ & $\begin{array}{c}\text { The activity } \\
\text { diameter of the } \\
\text { zone of } \\
\text { inhibition } \\
(\mathrm{mm}) \pm \mathrm{SD}\end{array}$ & $\begin{array}{l}\text { Inhibition zone } \\
\text { activity (8) }\end{array}$ \\
\hline \multirow{9}{*}{ APD7 } & \multirow{3}{*}{$\begin{array}{l}\text { Bacterial } \\
\text { Culture }\end{array}$} & E. coli & $2,6 \pm 0,05$ & $3,2 \pm 0,2$ & $0,6 \pm 0,2$ & Weak \\
\hline & & P. aureginosa & $4,3 \pm 0,05$ & $8,3 \pm 0,15$ & $4 \pm 0,15$ & Weak \\
\hline & & S. aureus & $2,6 \pm 0,05$ & $4,4 \pm 0,20$ & $1,8 \pm 0,2$ & Weak \\
\hline & \multirow{3}{*}{$\begin{array}{c}\text { Bacterial } \\
\text { Supernatant }\end{array}$} & E. coli & 6 & $8,9 \pm 0,2$ & $2,9 \pm 0,2$ & Weak \\
\hline & & P. aureginosa & 6 & $8,2 \pm 0,15$ & $2,7 \pm 0,15$ & Weak \\
\hline & & S. aureus & 6 & $8 \pm 0,2$ & $2 \pm 0,11$ & Weak \\
\hline & \multirow{3}{*}{ Bacterial Pellet } & E. coli & 6 & $8,9 \pm 0,15$ & $2,9 \pm 0,2$ & Weak \\
\hline & & P. aureginosa & 6 & $8,2 \pm 0,05$ & $2,7 \pm 0,2$ & Weak \\
\hline & & S. aureus & 6 & $8 \pm 0$ & $2 \pm 0,11$ & Weak \\
\hline
\end{tabular}

Note: SD: Standard Deviation

The APD7 isolate showed various spectrum in inhibiting the test pathogens with each method. Different antibacterial spectrum shows the diversity of bioactive compounds produced by bacteria associated with the sponge as their host. These different compounds are thought in inhibiting colonization of the test pathogens. According to [11], the production of antimicrobials is regulated by overall regulatory controls that play a role in the growth rate and special regulatory effects on each metabolic pathway, genetic factors and media composition. According to [12], the production of bioactive compounds from bacteria is also related to the growth phase of bacteria. When bacteria enter the logarithmic phase, then in this phase the bacteria will carry out cell division and require a lot of nutrients available in the media. When the nutrients in the media are reduced, in this phase the bacteria will enter a stationary phase and it is suspected that the production of bioactive compound will occur on of which is a microbial compound.

Measurement of the diameter of bacterial isolate and the inhibition zone of antibacterial producing bacteria using isolate, pellet, and supernatant culture was carried out with a digital caliper and three repetitions to be continued with the calculation of standard deviation. The standard deviation value in the Table 1 for each measurement has different values ranging from 0-0,2 Standard deviation can be used to determine the accuracy of the meter in making measurements. According to [13], the standard deviation of a data set is equal to zero which indicates that all values in the set are the same, while a larger deviation value indicates that the individual data points are far from the average. 


\subsection{Identification of the APD7 isolate by Gram Staining and Biochemical Test}

Bacterial identification was carried out to determine the character of the bacteria through morphological, biochemical and moleculer. Morphological identification was carried out with two observations, namely macroscopic and microscopic. Macroscopis observations were made by looking at the margin, texture, form, elevation, and color of the colony. Microscopic observations were made with gram stain.

Gram staining was performed to distinguish two groups of bacteria, namely Gram-positive and Gramnegative. Differences in the reponse of bacteria to the Gram staining mechanism are based on the structure and chemical components of the bacterial cell wall [9]. According [14], Gram-positive bacteria have thicker cell walls with the main component consisting of peptidoglycan and having a single cell membrane. Whereas Gram-negative bacteria have a thinner cell wall consisting of two layers of membranes. The inner membrane consists of peptidoglycan while the outer membrane is composed of lipopolysaccharides and lipoproteins. Gram-negative staining is indicated by bacteria that are red, while Gram-positive bacteria are purple. APD7 isolate was grouped into Gram-positive bacteria and has the shape of a coccus with staphylococci arrangement. The characters of Gramstaining of APD7 isolate can be seen in Figure 2.

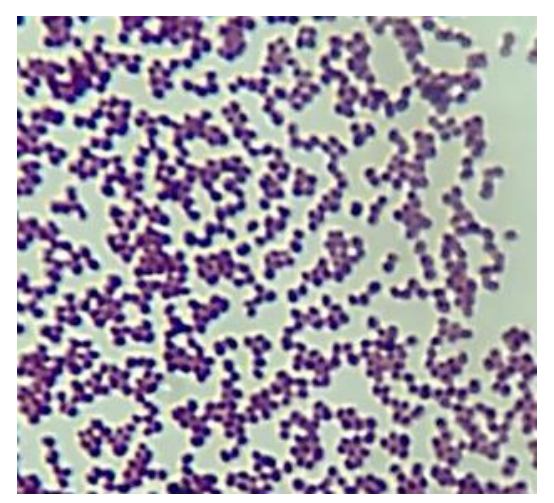

Figure 2. Gram-staining of APD7 isolate using a Binocular Microscope with a magnification of 1000x.

Biochemical tests were carried out to determine the physiological characterictics of bacteria. Bacteria used the nutrients obtained from the environment to carry out biochemical activities. Each bacterium is able to use the various enzymes present in its body to break down molecules such as carbodydrates, proteins, fats and nucleic acids. The difference in activity and the ability of each bacteria to use organic molecules can be used in the identification of bacteria. Morphological characterization and biochemical tests on APD7 isolate associated with Aplysina sp. sponge were shown in Table 2.

Table 2. Morphological observations and biochemical tests of APD7 isolate sponge-associated Aplysina sp.

\begin{tabular}{|c|c|c|c|c|c|c|c|c|}
\hline $\begin{array}{l}\text { Sample } \\
\text { code }\end{array}$ & \multicolumn{8}{|c|}{ Characterization of bacterial morphology } \\
\hline \multirow{6}{*}{ APD7 } & \multicolumn{2}{|c|}{ Margin } & Texture & \multicolumn{2}{|l|}{ Form } & Elevation & \multicolumn{2}{|c|}{ Colour } \\
\hline & \multicolumn{2}{|c|}{ Entire } & Smooth & \multicolumn{2}{|l|}{ Circular } & Flat & \multicolumn{2}{|c|}{ Cream } \\
\hline & \multicolumn{8}{|c|}{ Biochemical Test } \\
\hline & \multirow{2}{*}{$\mathbf{C}$} & \multirow{2}{*}{ Si } & \multirow{2}{*}{ Mo } & \multirow{2}{*}{$\mathbf{U}$} & \multicolumn{4}{|c|}{ Carbohydrate Fermentation Test } \\
\hline & & & & & $\mathbf{G}$ & $\mathbf{M}$ & $\mathbf{L}$ & $\mathbf{S}$ \\
\hline & + & - & - & + & + & + & + & + \\
\hline
\end{tabular}

Note: $\mathrm{C}=$ Catalase test $\mathrm{Si}=$ Citrate test $\mathrm{Mo}=$ Motility test $\mathrm{U}=$ Urea test $\mathrm{G}=$ Glucose test, $\mathrm{M}=$ Maltose test, $\mathrm{L}=$ Lactose test, $\mathrm{S}=\mathrm{Sucrose}$

test

In the urea test, APD7 isolate was able to hydrolyze urea, this indicated that APD7 isolate had urease enzyme. According [9], that some microbes produce urease enzyme which break down urea into ammonium and $\mathrm{CO}_{2}$. The presence of ammonia forms an alkaline environment which causes the $\mathrm{pH}$ of the media to become alkaline so that the color changes from yellow to purplish red [15]. APD7 showed a positive reaction to 4 types of carbohydrates, such as glucose, sucrose, lactose and maltose. In the Carbohydrate Fermentation Test aims to determine the ability of bacteria to ferment carbohydrates to produce acid.

Positive result in acid formation can be seen from the change in the color of the media from red to yellow and the formation of gas in the durham tube. The change in color to yellow is due to the phenol red indicator in the media [9].

\subsection{Moleculer Identification of APD7 Isolates Based on the 16S rRNA Gene Sequence}

APD7 isolate is one of the isolates that hasantibacterial activity ability of the 16 isolates associated with Aplysina sp. sponge. APD7 isolate was identified and amplified by the $16 \mathrm{~S}$ rRNA gene by PCR machine using primers $63 \mathrm{~F}$ and $1387 \mathrm{R}$. the results of DNA amplification were analyzed using $1 \%$ agarose gel electrophoresis technique. The DNA that was successfully amplified was characterized by the formation of a DNA fragment measuring $1300 \mathrm{bp}$ (Figure 3). 
Table 3. Molecular Identity of APD7 isolate based on $16 \mathrm{~S}$ rRNA genes using BLASTn

\begin{tabular}{|c|c|c|c|c|c|}
\hline Isolate & Homology & $\begin{array}{c}\text { Query Cover } \\
(\%)\end{array}$ & E-value & Similarity & Access Number \\
\hline \multirow{4}{*}{ APD7 } & $\begin{array}{l}\text { Staphylococcus sciuri strain TY- } \\
42\end{array}$ & 99 & 0.0 & $99.55 \%$ & MT550814.1 \\
\hline & Staphylococcus sciuri strain CB212 & 99 & 0.0 & $99.55 \%$ & MT527534.1 \\
\hline & $\begin{array}{l}\text { Staphylococcus sciuri strain } \\
\text { KUBOTAB3 }\end{array}$ & 99 & 0.0 & $99.55 \%$ & MK855403.1 \\
\hline & Staphylococcus sciuri strain AA1 & 99 & 0.0 & $99.55 \%$ & МТ275460.1 \\
\hline
\end{tabular}

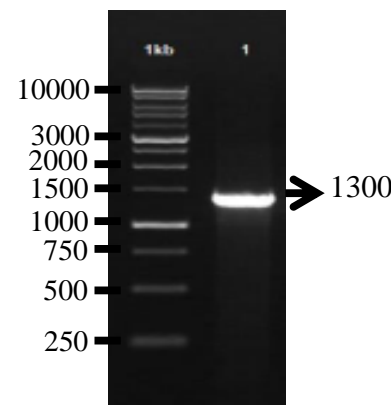

A

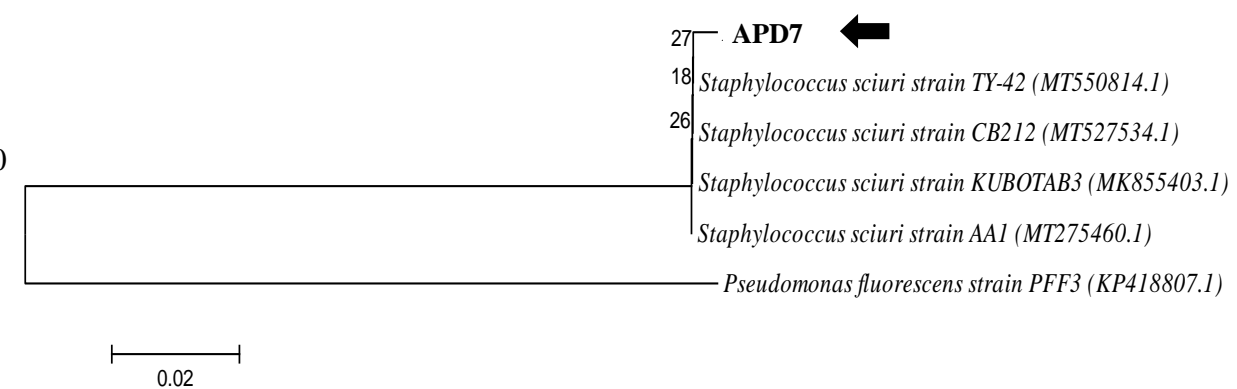

B

Figure 3. $16 \mathrm{~S}$ rRNA gene electrophoresis resulted in sized DNA bands $\sim 1300 \mathrm{pb}$. (1kb) marker $1 \mathrm{~kb}(\mathrm{~A})$, and Phylogenetic tree of APD7 isolate based on 16S rRNA genes sequences using the Neighbor Joining Tree method with a bootstrap value of 1000x replicates (B)

Based on BLASTn APD 16 isolate had genetically similarities with Staphylococcus sciuri strain TY-42, Staphylococcus sciuri strain CB212, Staphylococcus sciuri strain KUBOTAB3, Staphylococcus sciuri strain AA1 with a similarity value of $99.55 \%$ (Table 3 ). According [16], that the similarity of $16 \mathrm{~S}$ rRNA gene sequences which is more than $97 \%$ can be said to be the same species. And according to [17], that the similarity of the $16 \mathrm{~S}$ rRNA genes sequences which is less than $97 \%$ can be indicated as a new species, the similarity of the sequences between $93-97 \%$ can be indicated at the same genus level but different species.

The alignment of the sequence with the $16 \mathrm{~S}$ rRNA gene in APD7 isolate resulted in an E-value of $0.0 \%$ which indicates a high homology between aligned sequences. According [18], the Cover query is the presentation of the same nucleotide length as the database sequence in BLAST. The E-value is an estimated value that shows a statistically significant measure for both sequences. The higher the E-value, the lower the homology value between the two sequences, conversely the lower the E-value, the higher the homology between the two sequences.

The construction of phylogenetic trees based on the $16 \mathrm{~S}$ rRNA coding gene was carried out using Neighbor-Joining method with a bootstrap value of 1000 replications. Phylogenetic tree construction analysis aims to determine the exact relationship between bacterial isolates using the $16 \mathrm{~S}$ rRNA gene sequence. The phylogenetic tree design (Figure 3B) showed that APD7 isolate had homology of $16 \mathrm{~S}$ rRNA gene sequences with Staphylococcus sciuri which is Gram-positive in nature and is clearly far apart from Pseudomonas aeruginosa strain PFF3 (outgroup) which is Gram-negative. The purpose of using the outgroup is to determine the parameters of suitability and accuracy of bacterial isolates based on the 16S rRNA gene sequence in phylogenetic tree construction.

\section{CONCLUSION}

A total of successfully 16 bacterial isolates were collected from the sponge Aplysina sp. Antimicrobial compounds from bacteria-associated with the sponge Aplysina sp against Escherichia coli, Pseudomonas aeruginosa and Staphylococcus aureus with the code APD7. Based on their Gram-staining and biochemical test APD7 isolate have close relative with Staphylococcus, and based on molecular identification use $16 \mathrm{~S}$ rRNA gene, APD7 isolate had genetically similarities with Staphylococcus sciuri. 


\section{ACKNOWLEDGMENT}

The author would like to thank to Research and Community Services Centre (LPPM) University of Bengkulu through 2020 Research Grant (Hibah Unggulan Fakultas MIPA) Grant number: 2049 / UN30.12 / HK / 2020 dated 09 July 2020 to Risky Hadi Wibowo. The author also thanks to the people of Enggano Island, Bengkulu Province, and all parties who have helped the completion of this research.

\section{REFERENCES}

[1] W.E.G. Muller, V.A. Grebenjuk, N.L. Thakur, A.N. Thakur, R. Batel, A. Krasko, H.J. Breter, Oxygen-Controlled Bacterial Growth in the Sponge Suberites domuncula: toward a Molecular Understanding of the Symbiotic Relationships between Sponge and Bacteria, Applied and Enviromental Microbiology 70(4) (2004) 2332-2341. DOI: 10.1128/AEM.70.4.2332-2341.2004

[2] G. Wang, Diversity and Biotechnological Potential of The Sponsassociated Microbial Consortia, Journal of Industrial Microbiology and Biotechnology 33(7) (2006) 545-551. DOI: $10.1007 / \mathrm{s} 10295-006-0123-2$

[3] L. Zheng, H. Chen, X. Han, X. Yan, Antimicrobial Screening and Active Compound Isolation from Marine Bacterium NJ6-3-1 Associated with The Sponge Hymeniacidon perleve, World Journal of Microbiology Biotechnology 21(2) (2005) 201206. DOI: $10.1007 / \mathrm{s} 11274-004-3318-6$

[4] M.H. Kreuter, R.E. Leake, F. Rinaldi, W. Muller-Klieser, W.E.G. Muller, H.C. Schroder, Inhibition of Intrinsic Protein Tyrosine Kinase Activity of EGF-Receptor Kinase Complex from Human Breast Cancer Cells by The Marine Sponge Metabolite (+)-aeroplysinin-1, Comparative Biochemistry and Physiology 97(1) (1990) 151-158. DOI: 10.1016/03050491(90)90194-x

[5] B. Weiss, R. Ebel, Elbrachter, M. Kirchner, P. Proksch, Defense Metabolites from The Marine Sponge Verongia aerophoba, Biochemical Systematics and Ecology 24(1) (1996) 1-12. DOI: $10.1016 / 0305-1978(95) 00101-8$

[6] U. Hentschel, M. Schmid, M. Wagner, F. Lars, C. Gernert, H. Jorg, Isolation and phylogenetic analysis of bacteria with antimicrobial activities from the Mediterranean sponges Aplysina aerophoba and Aplysina cavernicola. Microbiology Ecology 35(3) (2001) 305-312. DOI: 10.1111/j.1574-6941.2001.tb00816.x
[7] R.W. Newbold, P.R. Jensen, W. Fenical, J.R. Pawlik, Antimicrobial activity of Caribbean sponge extracts. Aquatic microbial ecology 19(3) (1999) 279-284. DOI:10.3354/ame019279

[8] W.W. Davis, T.R. Stout, Disc Plate Method of Microbiological Antibiotic Assay. Applied Microbiology, Vol. 22(4) (1971) 659-665. PMID: 5002143

[9] B.W. Lay, Analisis Mikrob di Laboratorium, Jakarta, PT Raja Grafindo Persada, 1994. [In Bahasa Indonesia]

[10] J.R. Marchesi, S. Takuichi, J.W. Andrew, A. Martin, C.F. John, J.H. Sarah, G.W. William, A.M. Tracey, Design and Evaluation of Useful BacteriumSpecific PCR Primers That Amplify Genes Coding for Bacterial 16S rRNA Design and Evaluation of Useful Bacterium-Specific PCR Primers That Amplify Genes Coding for Bacterial 16S rRNA, American Sociaty for Microbiology 64(2) (1998) 795-99. PMID: 9464425

[11] T. Purwoko, Fisiologi Mikroba, Jakarta, PT Bumi Aksara, 2007.

[12] R. Nofiani, S. Nurbetty, A. Sapar, Aktivitas Antimikroba Ekstrak Metanol Bakteri Berasosiasi Spons dari Pulau Lemukutan, Kalimantan Barat, EJurnal Ilmu Dan Teknologi Kelautan Tropis 1(2) (2009) 33-41. [In Bahasa Indonesia]

[13] Mikhail, Gracie, Analysis and Adjustment of Survey Measurement, Van. Nostrand Reinhold Company Inc, 1981 .

[14] K. Irianto, Mikrobiologi Menguak Dunia Mikroorganisme, Bandung, CV. Yrama Widya, 2006. [In Bahasa Indonesia]

[15] J.G. Cappuccino, N. Sherman, Microbiology A Laboratory Manual tl (Tenth Edition). New York (US), Pearson Education, 2014.

[16] A. Hagstrom, J. Pinhassi, U.L. Zweifel, Biogeographical Diversity Among Marine Bacterioplankton, Aquatic Microbial Ecology 21(3) (2000) 231-244.

[17] E. Stackebrandt, B.M. Goebel, Taxonomic Note : A Place for DNA-DNA Reassociation and 16s rRNA Sequence Analysis in the Present Species Definition in Bacteriology, International Journal Of Systematic Bacteriology44(4) (1994) 846-849.

[18] J.M. Claverie, C. Notredame, Bioinformatics for dummies, Hoboken, Wiley Publishing, 2007. 